\title{
Absorption of $1.5 \%$ glycine after percutaneous ultrasonic lithotripsy for renal stone disease
}

\author{
JOHN F SINCLAIR, ALAN HUTCHISON, R BARAZA, A B M TELFER
}

\begin{abstract}
An elderly normotensive man underwent percutaneous ultrasonic lithotripsy for renal stone disease, the procedure lasting three hours and the fragments being washed out with $2011.5 \%$ glycine. After two hours the inflation pressure had risen to $25 \mathrm{~cm}$ $\mathrm{H}_{2} \mathrm{O}$ and his blood pressure to $150 \mathrm{~mm} \mathrm{Hg}$. Inflation pressure continued to rise until drainage tubes were inserted into the retroperitoneal space, releasing a large volume of fluid, some of which appeared to be from the peritoneal cavity. Shortly after transfer to the recovery area the patient showed signs of the transurethral resection syndrome, with hyponatraemia, hyperkalaemia, and hypertension. He was treated appropriately and survived.

Low infusion pressures should be used for irrigation during lithotripsy and $0.9 \%$ saline instead of $1.5 \%$ glycine. In patients given a general anaesthetic any rise in inflation pressure suggests extravasation of fluid and warrants emergency estimation of the plasma sodium concentration.
\end{abstract}

\section{Introduction}

A case of extravasation of $1.5 \%$ glycine irrigant into the retroperitoneal space during percutaneous ultrasonic lithotripsy is reported. The patient developed the transurethral resection syndrome ${ }^{1}$ of hyponatraemia, hyperkalaemia, and hypertension. Similar cases have recently been described. ${ }^{23}$ We report our experience with this syndrome.

\section{Case history}

A 68 year old man presented with haematuria, proteinuria, back pain, and frequency of micturition. An intravenous pyelogram showed a right rena calculus. His medical history contained nothing else of note and he was normotensive $(130 / 80 \mathrm{~mm} \mathrm{Hg})$.

Ultrasonic lithotripsy entails inserting a percutaneous guide wire into the renal collecting system under $x$ ray control. The track is then dilated and an endoscope passed along it. An ultrasonic probe is inserted to disintegrate the stone.

After insertion of the percutaneous guide wire anaesthesia was induced and intermittent positive pressure ventilation begun. The initial inflation pressure was $18 \mathrm{~cm} \mathrm{H}_{2} \mathrm{O}$ with the patient in the prone position. The procedure lasted three hours, during which $2011.5 \%$ glycine was used as irrigation fluid. After two hours the inflation pressure had risen to $25 \mathrm{~cm} \mathrm{H}_{2} \mathrm{O}$ and the systolic blood pressure to $150 \mathrm{~mm} \mathrm{Hg}$ despite increments of muscle relaxant and analgesia. The inflation pressure continued to rise to $35 \mathrm{~cm} \mathrm{H} \mathrm{H}_{2} \mathrm{O}$ by the end of the procedure. On turning the patient supine the abdomen was noted to be grossly distended and tense. Drainage tubes were inserted into the retroperitoneal space and a large volume of fluid released, some of which appeared to be from the peritoneal cavity.

The inflation pressure fell to $20 \mathrm{~cm} \mathrm{H}_{2} \mathrm{O}$ and the patient was transferred to the recovery area. A few minutes later the blood pressure rose to $250 / 140 \mathrm{~mm} \mathrm{Hg}$ before being controlled by an infusion of sodium nitroprusside. In view of the possibility of the transurethral resection syndrome $100 \mathrm{ml}$ sodium bicarbonate $8.4 \%(100 \mathrm{mmol}(\mathrm{mEq})$ sodium $)$ was given. The table shows the initial blood gas and serum electrolyte values. An infusion of $1.8 \%$ saline was then begun and $50 \mathrm{ml}$ dextrose $50 \%$ with 20 units neutral insulin administered. Mannitol $20 \% 100 \mathrm{ml}$ and initially frusemide $10 \mathrm{mg}$ were also given. Two hours later, after $1000 \mathrm{ml} 1 \cdot 8 \%$ saline, the serum electrolyte concentrations had improved considerably (table). The patient was ventilated overnight. Serial glycine concentrations confirmed the absorption of large amounts of glycine $(5779 \mu \mathrm{mol} / \mathrm{l}(434.0 \mu \mathrm{g} / \mathrm{ml})$ postoperatively; in a subsequent patient concentrations measured during an uneventful percutaneous ultrasonic lithotripsy did not rise above $412 \mu \mathrm{mol} / 1$ $(31.0 \mu \mathrm{g} / \mathrm{ml}))$. One month later the patient was well and pain free.

\section{Comment}

Acute water overload with severe hyponatraemia is a potentially fatal complication of percutaneous ultrasonic lithotripsy. Glycine $1.5 \%$ is hypotonic (osmolality $200 \mathrm{mmol}(\mathrm{mosmol}) / \mathrm{kg}$ ) and will cause intravascular haemolysis if large quantities are absorbed. In percutaneous ultrasonic lithotripsy its non-electrolytic nature 


\begin{tabular}{|c|c|c|c|c|c|c|c|c|c|c|c|c|}
\hline Date and time & $\begin{array}{l}\text { Sodium } \\
\text { mmol 1 }\end{array}$ & $\begin{array}{l}\text { Potassium } \\
\text { (mmol l })\end{array}$ & $\begin{array}{l}\text { Chloride } \\
\text { (mmol } 1)\end{array}$ & $\begin{array}{l}\text { Carbon } \\
\text { dioxide } \\
\text { mmol l })\end{array}$ & $\begin{array}{l}\text { Urea } \\
\text { (mmol I })\end{array}$ & $\begin{array}{l}\text { Creatinine } \\
(\mu \mathrm{mol} / \mathrm{l})\end{array}$ & $\begin{array}{c}\text { Fractional } \\
\text { inspired } \\
\text { oxygen }\end{array}$ & $\begin{array}{c}\text { Hydrogen } \\
\text { (nmoli) }\end{array}$ & $\begin{array}{c}\text { Arterial } \\
\text { partial } \\
\text { pressure of } \\
\text { carbon } \\
\text { dioxide } \\
(\mathbf{k P a})\end{array}$ & $\begin{array}{c}\text { Base } \\
\text { excess } \\
(\text { mmol/l) })\end{array}$ & $\begin{array}{c}\text { Arterial } \\
\text { partial } \\
\text { pressure } \\
\text { of oxygen } \\
(\mathrm{kPa})\end{array}$ & $\begin{array}{l}\text { Glycine } \\
\text { ( } \mu \mathrm{mol} / \mathrm{l}) \\
\text { (normal } \\
176-332)\end{array}$ \\
\hline Before operation & 141 & $4 \cdot 3$ & 100 & 31 & $6 \cdot 3$ & 100 & & & & & & \\
\hline $17 \operatorname{Sept}\left\{\begin{array}{l}1745 \\
2000 \\
2400\end{array}\right.$ & $\begin{array}{l}108^{\star} \\
132 \\
134\end{array}$ & $\begin{array}{l}6 \cdot 8^{\star} \\
3 \cdot 3 \\
3.9\end{array}$ & $\begin{array}{c}81^{\star} \\
94 \\
100\end{array}$ & $\begin{array}{l}18^{\star} \\
22 \\
23\end{array}$ & $\begin{array}{l}5 \cdot 7 \star \\
6 \cdot 5 \\
8 \cdot 8\end{array}$ & $\begin{array}{l}90^{\star} \\
130 \\
110\end{array}$ & $\begin{array}{l}0.4 \dagger \\
0.4 \dagger\end{array}$ & $\begin{array}{l}50 \dagger \\
50 \dagger\end{array}$ & $\begin{array}{l}5.6 t \\
5.3 t\end{array}$ & $\begin{array}{l}-5 t \\
-6 t\end{array}$ & $\begin{array}{l}15 \cdot 2 \dagger \\
10 \cdot 8 t\end{array}$ & $\begin{array}{l}5779 \\
3471 \\
1813\end{array}$ \\
\hline $18 \mathrm{Sept}\left\{\begin{array}{l}0800 \\
2000\end{array}\right.$ & 136 & $3 \cdot 7$ & 102 & 26 & $8 \cdot 9$ & 100 & $0 \cdot 21$ & 38 & $5 \cdot 5$ & +2 & $8 \cdot 8$ & 415 \\
\hline
\end{tabular}

*Hacmolysed.

trentilated.

Conversion: SI to traditional unts-Sodium, potassium, chloride: $1 \mathrm{mmol} \mathrm{l}=1 \mathrm{mEq} /$. Carbon dioxide: $1 \mathrm{mmol} / 1=4 \cdot 4 \mathrm{mg} / 100 \mathrm{ml}$. Urea $1 \mathrm{mmol} / \approx=6 \mathrm{mg} / 100 \mathrm{ml}$. Creatinine: $1 \mu \mathrm{mol} / \approx 0.01 \mathrm{mg} / 100 \mathrm{ml}$ Hydrogen: I nmol $l=1 \mathrm{pg} \mathrm{ml}$. Pressure of carbon dioxide: $1 \mathrm{kPa} \approx 7.5 \mathrm{~mm} \mathrm{Hg}$. Base excess: $1 \mathrm{mmol} /=1 \mathrm{mEq} / \mathrm{l}$. Pressure of oxygen: $1 \mathrm{kPa} \approx 7.5 \mathrm{~mm} \mathrm{Hg}$. Glycine: $1 \mu \mathrm{mol} / \mathrm{l} \approx 0.08 \mu \mathrm{g} / \mathrm{ml}$.

(which avoids dissipation of diathermy currents in prostatic surgery) is unnecessary. An isosmotic electrolytic solution such as $0.9 \%$ saline may be substituted. ${ }^{2}$ In the event of extravasation of this solution hyponatraemia and haemolysis would not occur and the slower rate of expansion of the intravascular space would be less of a challenge to the cardiovascular system.

In this case the infusion into the retroperitoneal space of a large volume of $1.5 \%$ glycine led to an increase in inflation pressure, an increase in intravascular volume with hypertension, and hyponatraemia and hyperkalaemia secondary to intravascular haemolysis. The signs and symptoms of acute hyponatraemia with water overload in the central nervous system (apprehension, restlessness, headache, nausea, vomiting, confusion, coma, convulsions, paralysis) are masked by general anaesthesia. Thus cardiorespiratory signs become important (severe hypertension, bradycardia, dyspnoea, cyanosis, increased amplitude of QRS complex, $\mathrm{T}$ wave inversion). ${ }^{34}$

To avoid extravasation of large quantities of irrigant solution we suggest the use of low infusion pressures $\left(60-70 \mathrm{~cm} \mathrm{H}_{2} \mathrm{O}\right)$ and measurement of the volume of irrigant going into and returning from the patient. To reduce the effects of extravasation should it occur the use of $0.9 \%$ saline as irrigant solution is suggeted and regional anaesthesia will allow detection of early changes in the central nervous system. With general anaesthesia raised inflation pressure suggests extravasation and, if suspected, emergency estimation of the plasma sodium concentration should be carried out.

We thank Mr R Scott for his permission to report this case.

\section{References}

1 Creevy CD. Hemolytic reactions during transurethral prostatic resection. $\mathcal{f}$ Urol 1947;58:125-31. 2 Peterson GN, Kreiger JN, Glauber DT. Anaesthetic experience with percutaneous lithotripsy. Anaesthesia 1985; 40:460-4.

3 Shultz RE, Hanno PM, Wein AJ, Levin RM, Pollack HM, Van Arsdalen KN. Percutaneous ultrasonic lithotripsy: choice of irrigant. $\mathcal{F}$ Urol 1983;130:858-60.

4 Marx GF, Orkin LR. Complications associated with transurethral surgery. Anesthesiology 1962;23:802-13.

(Accepted 2 fuly 1985)

\title{
Prolonged use of nitrazepam for epilepsy in children with tuberous sclerosis
}

\author{
JENNIFER DENNIS, ANN HUNT
}

\begin{abstract}
A case note study of 90 children with tuberous sclerosis showed that $\mathbf{5 6}$ had taken nitrazepam for seizures for from one month to 13 years. In 38 children nitrazepam was withdrawn but only two had immediate major seizures. Given that sleepiness, deterioration in motor skills, or ataxia seems to be associated in some children with treatment with nitrazepam, doctors may wish to review their long term prescriptions of this drug in children with tuberous sclerosis.
\end{abstract}

\footnotetext{
Human Development Research Unit, Park Hospital for Children, Headington, Oxford OX3 7LQ

JENNIFER DENNIS, DM, DCH, associate specialist in mental handicap ANN HUNT, BA, research worker

Correspondence to: Dr Jennifer Dennis.
}

\section{Introduction}

Nitrazepam has been used since the 1960s to treat those myoclonic epilepsies of infancy and childhood that do not respond to general anticonvulsants. ${ }^{1}$ Tolerance may develop within months, leading to increased doses over time. ${ }^{2}$ No controlled study of this use of nitrazepam exists, and little attention has been paid to its possible side effects in small children.

\section{Method and results}

We made a case note study of 90 children with tuberous sclerosis attending hospital paediatric departments in Great Britain. The children were aged 5 or more at the time of the study.

Out of 86 children with seizures, 73 had had infantile spasms or childhood myoclonic epilepsy, or both. Fifty six had been given nitrazepam for from one month to 13 years. In 26 children seizures were moderated or stopped for at least a few months after nitrazepam was administered. No change in pattern or number of seizures was recorded for the 30 other children. The obvious consequence should therefore have been to stop giving the drug to these children. This was not necessarily the case. 